\title{
Continuous Production of Pectinase by Immobilized Yeast Cells on Spent Grains
}

\author{
CATARINA ALMEIDA, ${ }^{1,2}$ TOMÁŠ BRÁNYIK, ${ }^{1}$ \\ PEDRO MORADAS-FERREIRA, ${ }^{3}$ AND JOSÉ TEIXEIRA ${ }^{1 *}$ \\ Centro de Engenharia Biológica, Universidade do Minho, Campus de Gualtar, 4710-057 Braga, Portugal, ${ }^{1}$ \\ Instituto Superior de Ciências da Saúde-Sul, Quinta da Granja, 2829-511 Monte da Caparica, Portugal, ${ }^{2}$ \\ and Instituto de Ciências Biomédicas Abel Salazar. Universidade do Porto, \\ Largo Prof. Abel Salazar, 2-P-4099-003 Porto, Portugal
}

Received 15 April 2003/Accepted 2 September 2003

\begin{abstract}
A yeast strain secreting endopolygalacturonase was used in this work to study the possibility of continuous production of this enzyme. It is a feasible and interesting alternative to fungal batch production essentially due to the specificity of the type of pectinase excreted by Kluyveromyces marxianus CCT 3172, to the lower broth viscosity and to the easier downstream operations. In order to increase the reactors' productivity, a cellulosic carrier obtained from barley spent grains was tested as an immobilization support. Two types of reactors were studied for pectinase production using glucose as a carbon and energy source - a continuous stirred tank reactor (CSTR) and a packed bed reactor (PBR) with recycled flow. The highest value for pectinase volumetric productivity $\left(P_{\mathrm{v}}=0.98 \mathrm{U} \mathrm{ml}^{-1} \mathrm{~h}^{-1}\right)$ was achieved in the $P B R$ for $D=0.40 \mathrm{~h}^{-1}$, a glucose concentration on the inlet of $S_{\mathrm{in}}=20 \mathrm{~g} l^{-1}$, and a biomass load in the support of $X_{\mathrm{i}}=0.225 \mathrm{~g} \mathrm{~g}^{-1}$. The results demonstrate the attractiveness of the packed bed system for pectinase production.
\end{abstract}

[Key words: continuous reactors, immobilized yeast cells, pectinase]

Pectinases are a group of enzymes responsible for the hydrolysis of pectic materials found in plants. They are important industrial enzymes, used for cloud point stabilization in juices, to increase pulp extraction from fruits and vegetables, in cocoa bean fermentation and for soluble tea preparations. More recently, they have been used in the textile industries for the degumming of fibre crops, in wastewater treatment and in the paper industries (1).

At present, pectinases are obtained from batch cultures of Aspergillus niger, a generally regarded as safe (GRAS) microorganism. Fungal batch cultures are generally a viscous, complex mixture of enzymes and metabolites. In fact, commercial pectinase is a blend of different enzymes with pectinolytic activity, together with amylases, arabinofuranidases, and other enzymes (2). Some GRAS yeast strains were found to excrete specific types of pectinolytic enzymes, allowing for the preparation of standardized enzyme mixtures for industrial use (2). Actually, there are processes using a specific type of pectinase, such as the preparation of citrus and orange juices, where endopolygalacturonases are preferred to maintain the turbidity and opaque aspect of juices (3). The main disadvantage for yeast pectinase production is the relatively low yield of these enzymes obtained by batch fermentation (2). The use of a pectinase producing yeast, together with the possibility of operating in continuous bioreactors with immobilized cells, would be an interesting alternative.

\footnotetext{
* Corresponding author. e-mail: jateixeira@deb.uminho.pt phone: +351-253-604406 fax: +351-253-678986
}

The yeast Kluyveromyces marxianus CCT 3172, isolated from a cocoa fermentation in Brazil $(4,5)$, was selected due to its relatively high yields of endopolygalacturonase production and was used in this work.

As a way to increase the productivity of continuous bioreactors, a high cell density is desirable and can be achieved using immobilized cells. Besides materials used for cell entrapment (such as alginate, pectate, carrageenan, kappacarrageenan, agar and synthetic polymers) and retention membranes forcing the cells to remain inside the reactor, yeast cells can be immobilized on the surface of porous glass, kieselguhr, wood chips, cellulosic fibers and cellulose derivatives, activated charcoal and artificial polymers (616). For industrial purposes, an important choice criterion is the carriers' cost, which, combined with the interest in byproducts reuse and valuation, led to an increased search for cheap and available potential cell carriers. Work has been developed in order to produce efficient cellulosic carriers from different origins, since cellulosic materials have a wide variety of physical and chemical properties that allows them to be used in different immobilization systems (8). Several examples of their successful use can be found, such as continuous wine production by yeasts supported in delignified cellulosic materials (DCM) $(10,11)$, beer making using yeasts adsorbed in DEAE-cellulose (15) or in DCM (7), and immobilized kefir yeast fermentation of raw materials to obtain alcoholic drinks (6). Another example is the cellulosic carrier obtained from barley spent grains, a by-product from the brewing industries. In fact, it was found to be a very efficient carrier due to its high yeast loading capacity, easy 
preparation, reusability, availability and to its inert, nontoxic nature $(17,18)$.

The work described in this paper was focused on producing endopolygalacturonase using continuous bioreactors with immobilized yeast cells on barley spent grains. Two different reactor designs were tested where the volumetric pectinase productivity was the main target parameter.

\section{MATERIALS AND METHODS}

Media and strain In this work, the wild type $K$. marxianus CCT 3172 used to inoculate both continuous reactors was grown in $200 \mathrm{ml}$ (in 500-ml Erlenmeyer flasks) semi-synthetic media at $30^{\circ} \mathrm{C}, 120 \mathrm{rpm}$ for $24 \mathrm{~h}$.

The semi-synthetic media (SS) for yeast growth included $5 \mathrm{~g} l^{-1}$ $\mathrm{K}_{2} \mathrm{HPO}_{4}, 2 \mathrm{~g} l^{-1}\left(\mathrm{NH}_{4}\right)_{2} \mathrm{SO}_{4}, 0.4 \mathrm{~g} l^{-1} \mathrm{MgSO}_{4} \cdot 7 \mathrm{H}_{2} \mathrm{O}, 1 \mathrm{~g} l^{-1}$ yeast extract, and different concentrations of glucose $(10,20,30,40,80$ $\left.\mathrm{g} l^{-1}\right)$.

Preparation of the carrier The cellulosic carrier was obtained from spent grains as follows, according to the steps described by Brányik and co-workers $(17,18)$. One hundred g of dry spent grains was treated with acid $(1500 \mathrm{ml}$ of a $3 \%[\mathrm{v} / \mathrm{v}] \mathrm{HCl}$ solution, $60^{\circ} \mathrm{C}, 2.5 \mathrm{~h}$ ) in order to hydrolyze the starchy endosperm and embryo of the barley kernel. After cooling, it was washed with water and dried. The remaining solids (ca. $30 \mathrm{~g}$ ) were partially delignified with $\mathrm{NaOH}\left(500 \mathrm{ml}\right.$ of a $2 \%[\mathrm{w} / \mathrm{v}]$ solution, $30^{\circ} \mathrm{C}, 24 \mathrm{~h}$, $120 \mathrm{rpm}$ ). Several washing steps with water were needed to reach a neutral $\mathrm{pH}$. After drying, the carrier (ca. $10 \mathrm{~g}$ ) was ready to be used.

Enzyme assays The endopolygalacturonase activity in the reactor effluent was assessed using the method described by Honda and co-workers (19). One unit (U) is defined as $1 \mu \mathrm{mol}$ of galacturonic acid released after $1 \mathrm{~min}$ of hydrolysis of polygalacturonic acid in the presence of the enzyme at $40^{\circ} \mathrm{C}, \mathrm{pH} 4.1$.

Analytical methods Glucose concentration was determined by the DNS method for reducing sugars quantification (20). For total protein determination, the samples from reactors were centrifuged, filtered and then dialyzed with a 14000 MWCO membrane (Medicell International, London, UK) against cold distilled water for $16 \mathrm{~h}$. The Bradford method was followed (21), using the Coomassieblue reagent (Pierce, Rockford, IL, USA) in ELISA plates.

Protein adsorption on the carrier surface A pre-grown culture of K. marxianus CCT 3172 was separated by centrifugation. The pectinase-rich supernatant was used for adsorption quantification in three Erlenmeyer flasks $(40 \mathrm{ml}$ of supernatant in each one). Two different amounts of spent grains were inserted in two flasks $(0.50 \mathrm{~g}$ and $1.0 \mathrm{~g})$. The third flask was used as a control where no spent grains were added. All three flasks were shaken in an orbital shaker $\left(30^{\circ} \mathrm{C}, 120 \mathrm{rpm}\right)$. Samples were taken throughout $5 \mathrm{~h}$ and its free protein concentration (not adsorbed) was determined by reading the fluorescence intensity $(280 \mathrm{~nm} / 400 \mathrm{~nm})$.

Cell contact angle measurement A solution of $20 \mathrm{~g} l^{-1}$ of agar and $10 \%$ glycerol was cast on a microscope slide. Cell samples were taken from a continuous reactor outflow and washed with a solution with increasing ethanol concentration $(10 \%, 20 \%$ and $50 \%, \mathrm{w} / \mathrm{v}$ ). One milliliter of a cell suspension in $50 \%$ ethanol with an $A_{600 \mathrm{~nm}}=2.0$ was spread on the solidified agar and glycerol and allowed to dry. This step was repeated 4 times (22). Contact angles were measured at room temperature using water, formamide and $\alpha$-bromonaphtalene in a contact angle apparatus (Kruss, Hamburg, Germany) by the sessile drop technique. The total surface tension $\left(\gamma^{\text {tot }}\right)$ and its components $\left(\gamma^{\mathrm{LW}}, \gamma^{+}, \gamma^{-}, \gamma^{\mathrm{AB}}\right)$, the values of the free energy of interaction between cells and water $\Delta G_{\text {sws }}^{\text {tot }}$ and the components $\left(\Delta G_{\text {sws }}^{\mathrm{LW}}, \Delta G_{\text {sws }}^{\mathrm{AB}}\right)$ were calculated according to van Oss and co-workers $(23,24)$. The values of cell surface tension, base-treated carrier surface tension, free energy of interaction between cell surfaces and free energy of interaction between basetreated carrier surfaces are presented in Table 1. From these values, the free energy of interaction between $K$. marxianus cells and basetreated carrier $\Delta G_{\text {sws }}^{\text {tot }}$ was calculated (23).

Scanning electron microscopy (SEM) A sample of biocatalyst was taken from the continuous stirred tank reactor (CSTR), washed with water and with a solution of increasing ethanol concentration $(10 \%, 25 \%, 50 \%, 75 \%, 90 \%, 100 \%)$. It was allowed to dry for $5 \mathrm{~d}$ in an exicator and covered with a thin gold layer to allow for SEM observation.

Biomass quantification The free biomass concentration at the reactor outlet was measured by reading the absorbance of samples at $600 \mathrm{~nm}$ and then converting this value to dry weight per volume using an appropriate calibration curve.

To quantify the immobilized biomass in the CSTR, samples of $50 \mathrm{ml}$ (corresponding to approx. $0.7 \mathrm{~g}$ of biocatalyst) were withdrawn from the reactor with a syringe by a sterile procedure. The carrier with adsorbed yeast cells was allowed to settle and was gently washed with $200 \mathrm{ml}$ of distilled water. The resulting suspension was filtered and washed with water; the filter paper with carrier and immobilized cells was dried at $105^{\circ} \mathrm{C}$ for $16 \mathrm{~h}$. A washing step (during $24 \mathrm{~h}$ at $120 \mathrm{rpm}$ ) with a $3 \%(\mathrm{w} / \mathrm{v}) \mathrm{NaOH}$ solution released the attached biomass. After washing with distilled water and filtering, the biomass free carrier was dried at $105^{\circ} \mathrm{C}$ for $5 \mathrm{~h}$. The biomass weight was calculated as being the weight difference of the dry carrier before and after the $\mathrm{NaOH}$ washing (18). Corrections of the biomass weight for the losses of carrier itself were carried out by blank experiments with clean carrier. Biomass load was expressed as $\mathrm{g}_{\text {biomass }} \mathrm{g}^{-1}$ carrier.

Bioreactor operation Both reactors were sterilized for $3 \mathrm{~d}$ with a hypochlorite solution. After this period, 10 reactor volumes of sterile distilled water were used to wash the columns.

The CSTR was a Perspex column with a height to internal diameter ratio (H/Di) of 1.5 and an effective volume of $730 \mathrm{ml}$. The stirrer (a four-blade marine propeller with a diameter of $5 \mathrm{~cm}$ ) axis was centered and rotational speeds of $80 \mathrm{~min}^{-1}$ and $200 \mathrm{~min}^{-1}$ were tested. Inside the reactor, $15 \mathrm{~g}$ of sterilized carrier together with SS medium containing glucose $\left(10 \mathrm{~g} l^{-1}\right)$ were inoculated with a previously grown culture of $K$. marxianus CCT 3172 . After $24 \mathrm{~h}$ of batch growth, the continuous feeding was started and samples were taken for the different steady states from the outlet. To prevent contamination, sterilized air was continuously forced to the reactor headspace. Different dilution rates were used.

The packed bed reactor (PBR) was also a Perspex column, with an H/Di of 12 and an operation volume of $310 \mathrm{ml}$. Twenty-five $g$ of sterile dry carrier was aseptically inserted in the column and then

TABLE 1. Surface tension $\gamma^{\text {tot }}$ (apolar $\gamma^{\mathrm{LW}}$ and polar $\gamma^{+}, \gamma, \gamma^{\mathrm{AB}}$ components) and free energy of interaction $\Delta G_{\text {sws }}^{\text {tot }}$ (apolar $\Delta G_{\text {sws }}^{\mathrm{LW}}$ and polar $\Delta G_{\text {sws }}^{\mathrm{AB}}$ contributions) for cells K. marxianus CCT 3172 grown in batch and continuous culture, and for the base-treated carrier

\begin{tabular}{lccccccrrrr}
\hline & $\gamma^{\mathrm{LW}}$ & $\gamma^{+}$ & $\gamma$ & $\gamma^{\mathrm{AB}}$ & $\gamma^{\text {tot }}$ & $\Delta G_{\text {sws }}^{\mathrm{LW}}$ & $\Delta G_{\text {sws }}^{\mathrm{AB}}$ & $\Delta G_{\text {sws }}^{\text {tot }}$ & $\Delta G_{\text {cws }}^{\text {tot }}$ \\
\hline Cells from batch culture & 32.1 & 3.24 & 53.5 & 26.3 & 58.4 & -1.99 & 29.4 & 27.4 & 7.60 \\
Cells from continuous culture & 24.8 & 6.15 & 53.2 & 36.2 & 61.0 & -0.20 & 23.1 & 22.9 & 1.86 \\
Base treated carrier & 40.9 & 0.013 & 5.91 & 0.56 & 41.5 & -5.98 & -51.7 & -57.7 & - \\
\hline
\end{tabular}

All values in $\mathrm{mJ} \mathrm{m}^{-2}$. 
inoculated with a pre-grown yeast culture. After $24 \mathrm{~h}$ of batch growth in the reactor, continuous operation was started by feeding SS medium with $40 \mathrm{~g}^{-1}$ glucose at the bottom of the column. A recycle rate of $40 \mathrm{ml} \mathrm{h}^{-1}$ was used during the entire operation time, by reintroducing part of the exit to the bottom of the column.

For both reactors, the dilution rate was considered to be $D\left(\mathrm{~h}^{-1}\right)$ $=$ volumetric rate/total volume occupied by media and biocatalyst. All assays were performed at $25^{\circ} \mathrm{C}$.

\section{RESULTS AND DISCUSSION}

Cell immobilization The carrier is both irregular in shape and non-homogeneous in chemical composition, having "active sites" that are preferably colonized by yeasts. The differences in the carrier colonization, as seen on the SEM, reflect the non-homogeneous cell-carrier interactions (Fig. 1). On the sample, corresponding to $26 \mathrm{~d}$ of reactor operation, there is still a large area of non-colonized carrier, although a steady-state value was already attained for immobilized biomass load at this point.

The maximum immobilized biomass load obtained for strain K. marxianus CCT $3172\left(0.320 \mathrm{~g} \mathrm{~g}^{-1}\right)$ in the CSTR was significantly lower than the one achieved in previous work with Saccharomyces uvarum for beer fermentation (ca. $0.600 \mathrm{~g} \mathrm{~g}^{-1}$ ) (14). This can be explained both by differences between the growth conditions of the continuous cultures (substrate concentration, aeration, reactor design) and
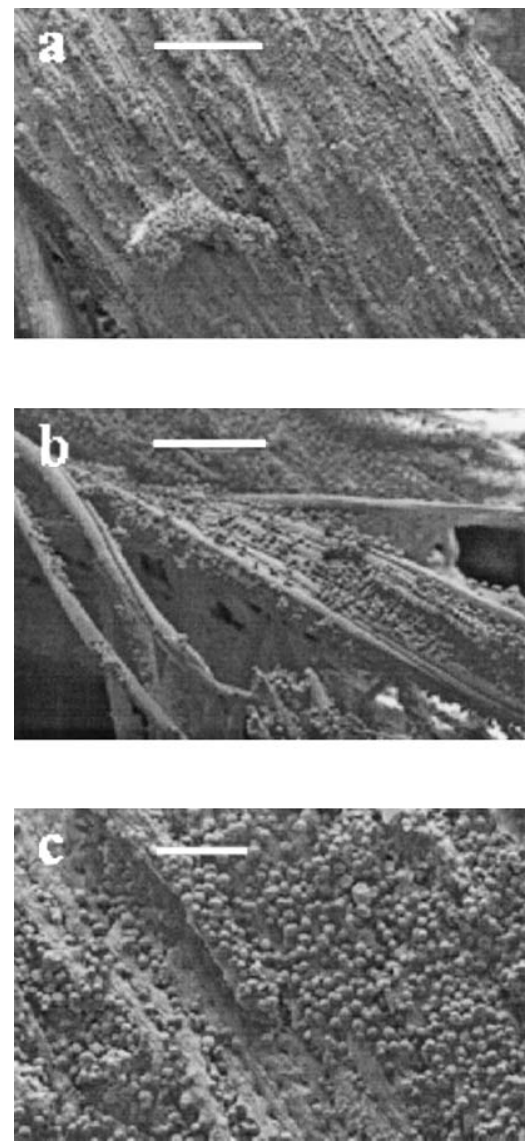

FIG. 1. SEM microphotographs of the biocatalyst sample; bars correspond to $100 \mu \mathrm{m}$ (a), $50 \mu \mathrm{m}$ (b) and $20 \mu \mathrm{m}$ (c). by different yeast surface properties.

Regarding the free energy of interaction between cells and carrier in water, the values $\left(\Delta G_{\mathrm{cws}}^{\mathrm{tot}}=7.60 \pm 7.05 \mathrm{~mJ} \mathrm{~m}^{-2}\right.$ for cells grown in batch culture and $\Delta G_{\mathrm{cws}}^{\mathrm{tot}}=1.86 \pm 8.70 \mathrm{~mJ}$ $\mathrm{m}^{-2}$ for cells at the outlet of the continuous reactor) showed an energetically less favorable adhesion between $K$. marxianus cells and the surface of spent grains particles in the presence of water compared to $S$. uvarum adhesion to spent grains, for which the free energy was $\Delta G_{\mathrm{cws}}^{\text {tot }}=-4.2 \pm 10 \mathrm{~mJ}$ $\mathrm{m}^{-2}$ (data not published). The results revealed a more important role of polar acid-base interactions $\left(\gamma^{\mathrm{AB}}, \Delta G_{\mathrm{sws}}^{\mathrm{AB}}\right)$ in the cell-cell adhesion of the $K$. marxianus cells, while the apolar interactions $\left(\Delta G_{\mathrm{sws}}^{\mathrm{LW}}\right)$ were almost negligible. Although the average free energy of interaction between $K$. marxianus cells from continuous culture and the spent grains surface in the presence of water was slightly higher than zero, negative values are included in the error bar, which shows that the cell-carrier adhesion can be energetically favorable. The standard error is relatively high due to the carrier's nonhomogeneous surface properties.

The higher hydrodynamic stress conditions in the CSTR (mechanical agitation) as opposed to the mild conditions in the air lift reactor (ALR) (18) can also account for a lower immobilized biomass load. Since this yeast strain does not secrete polysaccharides to help biofilm attachment, it can be assumed that the nature of the adhesion is likely to be influenced by shear stress.

In CSTR the immobilized biomass load reached a stationary value of approx. $0.200 \mathrm{~g} \mathrm{~g}^{-1}$ carrier after $9 \mathrm{~d}$ of continuous operation. When clean carrier was introduced (13 g), an increase in the stirrer rotational speed from $80 \mathrm{~min}^{-1}$ to $200 \mathrm{~min}^{-1}$ was needed to keep the biocatalyst in suspension. With this change in operating conditions, a cell load of $0.320 \mathrm{~g} \mathrm{~g}^{-1}$ was obtained (Fig. 2). The increased immobilized biomass load achieved when the stirrer speed was higher apparently contradicts the hypothesis of the shear stress induced yeast biofilm detachment. However, this observation could be explained by a disintegration of the spent grain particles as a result of the shear forces caused by increased stirrer speed, which increases the specific surface of the carrier available for cell attachment. Although no experimental evidence is available for this specific reactor,

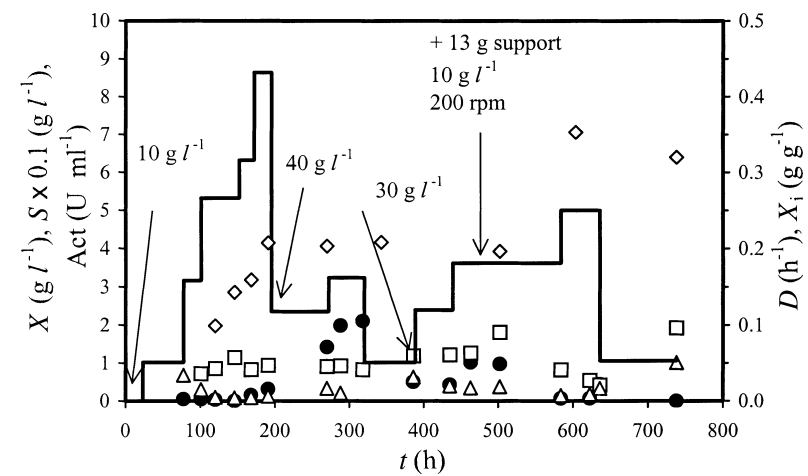

FIG. 2. Evolution of glucose concentration $S$ (circles), free biomass concentration $X$ (squares), pectinase activity Act (triangles), immobilized biomass $X_{\mathrm{i}}$ (lozenges), and dilution rate $D(-)$ during CSTR operation. The arrows mark the changes in the inlet glucose concentration, the addition of fresh carrier and the change in rotational speed. 


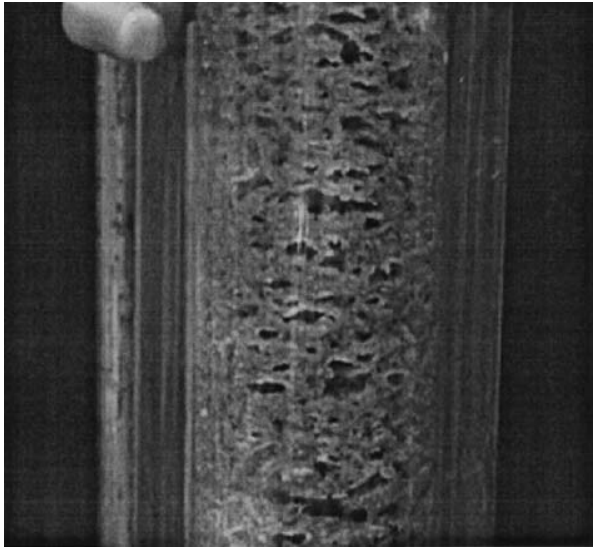

FIG. 3. View of the biocatalyst bed inside the PBR.

this observation is supported by previous studies with different initial particle surface areas (17). Besides, when the noncolonized carrier was introduced into the reactor (Fig. 2), the carrier-cell adhesion might have been enhanced both by the carrier's free active sites and by the increased number of hydrophobic cell wall areas of the continuous culture yeast cell population. Cell wall structure and properties change with cell age and with an increase in the number of hydrophobic scars during continuous culture (25).

In the case of the PBR, the carrier bed had a significantly different structure. Therefore, the sponge-like packing of the reactor (spent grains), besides the already mentioned immobilization mechanisms, worked as a filter layer allowing for local accumulations of yeast biomass visible to the naked eye. Due to the lack of the agitator, the metabolic $\mathrm{CO}_{2}$ formed in the course of the experiment created void spaces (bubbles) inside the carrier bed (Fig. 3). $\mathrm{CO}_{2}$ bubbles were periodically escaping through the top of the column. This movement caused some mixing in the packed bed and the release of biomass deposits. At the end of the operation time, the PBR reactor had a biomass load of $0.247 \mathrm{~g} \mathrm{~g}^{-1}$ carrier at the bottom and $0.204 \mathrm{~g} \mathrm{~g}^{-1}$ at the top.

Pectinase productivity The experiments dealing with pectinase productivity were carried out both in a CSTR and a PBR. During the operation of both reactors, the free bio-

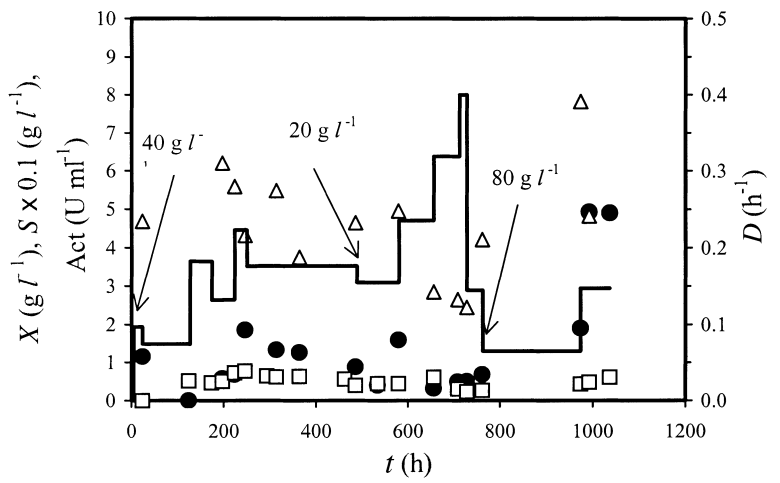

FIG. 4. Evolution of glucose concentration $S$ (circles), free biomass concentration $X$ (squares), pectinase activity Act (triangles), and dilution rate $D(-)$ during PBR operation. The arrows mark the changes in the inlet glucose concentration.
TABLE 2. Literature values for polygalacturonase production

\begin{tabular}{|c|c|c|c|}
\hline Source & $\begin{array}{l}\text { Productivity } \\
\left(\mathrm{U} \mathrm{ml}^{-1} \mathrm{~h}^{-1}\right)\end{array}$ & $\begin{array}{l}\text { Activity } \\
\left(\mathrm{U} \mathrm{ml}^{-1}\right)\end{array}$ & Reference \\
\hline A. niger $^{\mathrm{b}}$ & Not reported & 10.2 (free cells) & 30 \\
\hline A. niger $^{\mathrm{b}}$ & Not reported & 18.9 (immob. cells) & 30 \\
\hline G. klebahnii c & $12.8^{\mathrm{a}}$ & 40 (free cells) & 31 \\
\hline L. edodes ${ }^{\mathrm{b}}$ & $0.044^{\mathrm{a}}$ & 12.2 (solid state ferm.) & 32 \\
\hline K. marxianus $^{\mathrm{c}}$ & 0.75 & 11 (free cells) & Arnot, $1994^{\mathrm{d}}$ \\
\hline
\end{tabular}

${ }^{a}$ Calculated from reported culture times or dilution rates.

${ }^{\mathrm{b}}$ Batch cultures.

${ }^{c}$ Continuous cultures.

${ }^{\mathrm{d}}$ Arnot, T.C., Ph.D. thesis, Reading University, UK, 1994.

mass concentration, glucose concentration and pectinase activity were measured at the reactor outlets (Figs. 2 and 4). In the whole range of studied experimental conditions, significantly higher pectinase activities where found in PBR oscillating between $2.45 \mathrm{U} \mathrm{ml}^{-1}$ and $7.82 \mathrm{U} \mathrm{ml}^{-1}$, while in the CSTR the pectinase activities ranged from $0.08 \mathrm{U} \mathrm{ml}^{-1}$ to $1.01 \mathrm{U} \mathrm{ml}^{-1}$.

Several systems for polygalacturonase production have been tested and reported. Activity and productivity values found in the literature are presented in Table 2. The different methods used to determine the polygalacturonase activity, the different microbial sources and experimental arrangements account for the wide range of polygalacturonase activities and productivity values.

Endopolygalacturonase is produced by $K$. marxianus CCT 3172 as a primary metabolite $(4,26)$. In fact, the pectinase activity increased with total glucose consumption (Fig. $5)$ while the pectinase volumetric activity $\left(P_{\mathrm{V}}\right)$ is independent on this variable due to the changes occurring in dilution rate. This indicates that, for this bioreactor, there is a maximum capacity for glucose transformation in pectinase.

Using the PBR, the volumetric productivity values range from 0.61 to $0.98 \mathrm{U} \mathrm{h}^{-1} \mathrm{ml}^{-1}$ and increased with the dilution rate for the inlet glucose concentrations $\left(S_{\text {in }}\right)$ tested (Fig. 6). However, as can be seen in Fig. 4, the glucose was in most cases only partially consumed and this fact could lead to erroneous conclusions from a direct reading of Fig. 6 . When the specific pectinase production rate $\left(q_{\mathrm{p}}\right)$ and the specific glucose consumption rate $\left(q_{\mathrm{S}}\right)$ were represented (27), the same tendency for a linear increase with $D$ was found (Fig. 7). As it was not possible to withdraw samples from the

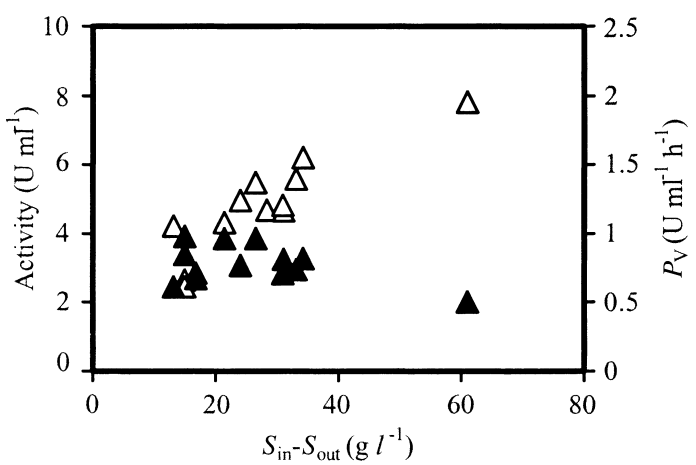

FIG. 5. Effect of the consumed glucose on pectinase activity (empty triangles) and volumetric productivity (filled triangles) in the PBR. 


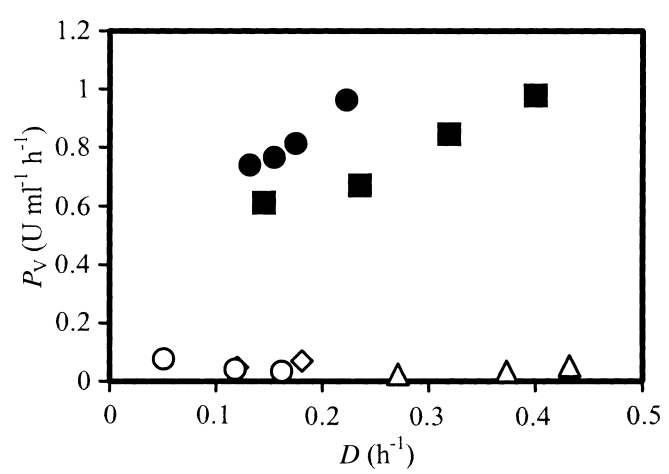

FIG. 6. Pectinase volumetric productivity for different inlet concentrations of glucose. PBR data are shown as filled symbols and CSTR data as empty symbols. Triangles correspond to $S_{\text {in }}=10 \mathrm{~g} l^{-1}$, squares to $S_{\text {in }}=20 \mathrm{~g} l^{-1}$, lozenges to $30 \mathrm{~g} l^{-1}$ and circles to $S_{\text {in }}=40 \mathrm{~g} l^{-1}$.

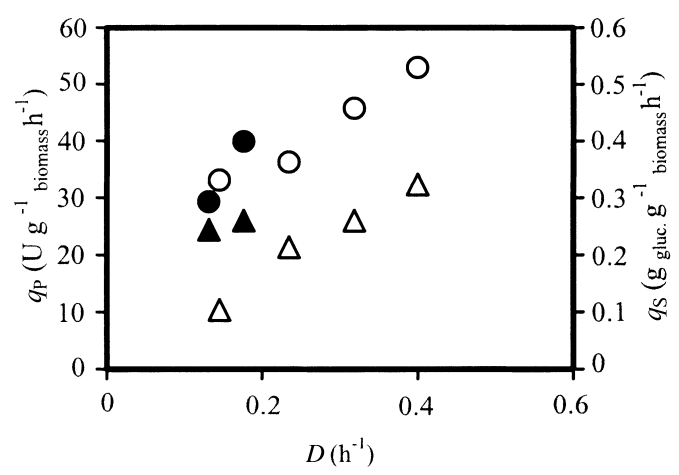

FIG. 7. Effect of the dilution rate on the specific pectinase production rate $\left(q_{\mathrm{p}}\right)$ (circles) and on the specific glucose consumption rate $\left(q_{\mathrm{s}}\right)$ (triangles) in the PBR. Empty symbols refer to $S_{\mathrm{in}}=20 \mathrm{~g} l^{-1}$, filled symbols refer to $S_{\mathrm{in}}=40 \mathrm{~g} l^{-1}$.

packed bed throughout the operation time, these values were calculated assuming that $150 \mathrm{~h}$ from the beginning of continuous operation the immobilized biomass load was constant, with an average value of $0.225 \mathrm{~g} \mathrm{~g}^{-1}$ carrier, corresponding to a total biomass concentration of $18.5 \mathrm{~g} l^{-1}$. As a consequence of this, a continuous operation at a high dilution rate (optimized as a function of process economics and downstream separation procedures) together with lower inlet glucose concentrations should be preferred. The best operating conditions in the PBR were found to be at $D=$ $0.40 \mathrm{~h}^{-1}$ and an inlet sugar concentration of $20 \mathrm{~g} l^{-1}$.

As shown in Fig. 5, the CSTR pectinase productivity values were very low for all the dilution rates and glucose concentrations on the inlet. Although the different productivity values obtained for CSTR and PBR were not expected, some reasons could be found to explain it. It has been reported for several Kluyveromyces and Saccharomyces strains that the production of endopolygalacturonase depends upon the dissolved oxygen concentration in the culture media. Wimborne and Rickard (28) found that under anaerobic conditions, achieved by bubbling $\mathrm{CO}_{2}$ or $\mathrm{N}_{2}$, the enzyme was produced, but at $60 \%$ of oxygen saturation its production was completely repressed. Cruz-Guerreiro and co-workers (29) studied the strain $K$. marxianus CDBB-L-278 and found that a dissolved oxygen concentration of $3.3 \mathrm{mg}^{-1}$ was the
TABLE 3. Effect of oxygen presence/absence on yield $\left(Y_{\mathrm{PS}}\right)$, specific activity (Sp. act.), and productivity $\left(P_{\mathrm{V}}\right)$ in batch production of endopolygalacturonase by the strain $K$. marxianus CCT $3172^{\mathrm{a}}$

\begin{tabular}{lccc}
\hline & Non-gassed & $\begin{array}{c}\mathrm{N}_{2} \\
\left(0.79 l \mathrm{~min}^{-1}\right)\end{array}$ & $\begin{array}{c}\text { Air } \\
\left(0.98 l \mathrm{~min}^{-1}\right)\end{array}$ \\
\hline$Y_{\mathrm{PS}}\left(\mathrm{U} \mathrm{g} \mathrm{g}^{-1}\right.$ glucose $)$ & 79.5 & 62.6 & 21.8 \\
$\begin{array}{l}\text { Sp. act. } \\
\left(\mathrm{U} \mathrm{mg} \mathrm{m}^{-1} \text { total protein }\right)\end{array}$ & 175 & 105 & 47.0 \\
$P_{\mathrm{V}}\left(\mathrm{U} \mathrm{ml}^{-1} \mathrm{~h}^{-1}\right)$ & 0.105 & 0.011 & 0.040 \\
\hline${ }^{a}$ Pereira, M., Ph.D. thesis, University of Minho, Portugal, 2003.
\end{tabular}

threshold for repression of endoPG production, regardless of the culture temperature. An increase in temperature values (at the same $\mathrm{O}_{2} \%$ of saturation) improved the enzyme production, but the authors believe that this effect was directly related to the reduction of dissolved $\mathrm{O}_{2}$ concentration at higher temperatures. Studies of $K$. marxianus CCT 3172 with a $1.5-l$ batch reactor were performed and Table 3 summarizes the experimental results. The nonaerated reactor, where mixing was achieved only by mechanical stirring, proved to be the best choice in terms of pectinase yield and productivity (Pereira, M., Ph.D. thesis, University of Minho, Portugal, 2003).

Neither the PBR nor the CSTR had direct air injection, but in the CSTR an air inlet was placed at the top of the reactor, to avoid contamination through the stirrer insert. The continuous supply of sterile air into the headspace, together with the high stirring speed used during operation, provided the culture with dissolved oxygen, possibly enough to alter the cells physiological state towards low pectinase production.

An assay was performed to verify the extent of pectinase adhesion/adsorption at the surface of spent grains. After the first hour, during which a decrease in free protein was observed, no significant change was found in the protein concentration. The amount of protein adsorbed was $49 \pm 11$ $\mu \mathrm{g} \mathrm{g}^{-1}$ carrier. Therefore, it can be assumed that the carrier becomes saturated during the first hour of reactor operation, further pectinase adsorption being negligible.

K. marxianus CCT 3172 , the wild-type strain, was isolated from a cocoa fermentation, where its activity was related to the breakdown of the pectic materials on the surface of cocoa beans (4). Its optimal environment should therefore be a culture over a solid lattice, with no hydrodynamic stress and a very low oxygen concentration. These conditions are to a certain extent similar to those found inside the PBR. The highest volumetric productivity value $\left(P_{\mathrm{V}}=0.98\right.$ $\mathrm{U} \mathrm{ml}^{-1} \mathrm{~h}^{-1}$ ) (Fig. 6) is 10 times higher than the one obtained for $K$. marxianus strain CCT 3172 in a non-aerated batch culture (Table 3 ). A further improvement could be the addition of pectin (activator of pectinase production) into the media; however, this has already been tested with this strain (4) and no increase in pectinase activity was found in the broth.

\section{ACKNOWLEDGMENTS}

Catarina Almeida and Tomáš Brányik thank Fundação para a Ciência e a Tecnologia for providing the grants BD/18203/98 and SFRH/BPD/3541/2000. 


\section{REFERENCES}

1. Kashyap, D. R., Vohra, P. K., Chopra, S., and Tewari, R.: Applications of pectinases in the commercial sector: a review. Bioresour. Technol., 77, 215-227 (2001).

2. Blanco, P., Sieiro, C., and Villa, T. G.: Production of pectic enzymes in yeasts. FEMS Microbiol. Lett., 175, 1-9 (1999).

3. Manachini, P. L., Parani, C., and Fortina, M. G.: Pectic enzymes from Aspergillus pullulans LV10. Enzyme Microb. Technol., 10, 682-685 (1988).

4. Schwan, R. F. and Rose, A. H.: Polygalacturonase production by Kluyveromyces marxianus: effect of medium composition. J. Appl. Bacteriol., 76, 62-67 (1994).

5. Schwan, R. F., Cooper, R. M., and Wheals, A. E.: Endopolygalacturonase secretion by Kluyveromyces marxianus and other cocoa pulp degrading yeasts. Enzyme Microb. Technol., 21, 234-244 (1997).

6. Athanasiadis, I., Boskou, D., Kanellaki, M., and Koutinas, A. A.: Effect of carbohydrate substrate on fermentation by kefir yeast supported on delignified cellulosic materials. J. Agric. Food Chem., 49, 658-663 (2001).

7. Bekatorou, A., Soupioni, M. J., Koutinas, A. A., and Kanellaki, M. E.: Low-temperature brewing by freeze-dried immobilized cells. Appl. Biochem. Biotechnol., 97, 105-121 (2002).

8. Gemeiner, P., Štefuca, V., and Báleš, V.: Biochemical engineering of biocatalysts immobilized on cellulosic materials. Enzyme Microb. Technol., 15, 551-566 (1993).

9. Hartmeier, W.: Immobilized biocatalysts - an introduction. Springer Verlag, Berlin (1988).

10. Iconomou, L., Kanellaki, M., Voliotis, S., Agelopoulos, K., and Koutinas, A. A.: Continuous wine making by delignified cellulosic materials supported biocatalyst. An attractive process for industrial applications. Appl. Biochem. Biotechnol., 60, 303-313 (1996)

11. Ikonomopoulou, M., Kanellaki, M., Soupioni, M., and Koutinas, A. A.: Effect of freeze-dried immobilized cells on delignified cellulosic material in low-temperature and ambient-temperature wine making. Appl. Biochem. Biotechnol., 104, 23-36 (2003).

12. Mensour, N. A., Margaritis, A., Briens, C. L., Pilkington, H., and Russel, I.: Application of immobilized yeasts in the brewing industry, p. 661-671. In Wijffels, R. H., Buitelaar, R. M., Bucke, C., and Tramper, J. (ed.), Immmobilised cells: basics and applications. Elsevier Science B.V., Amsterdam (1996).

13. Navrátil, M., Gemeiner, P., Klein, J., Sturdik, E., Malovikova, A., Nahalka, J., Vikartovska, A., Dömény, Z., and Šmogrovičová, D.: Properties of hydrogel materials used for entrapment of microbial cells in production of fermented beverages. Artif. Cells Blood Substit. Immobil. Biotechnol., 30, 199-218 (2002).

14. Pilkington, H., Margaritis, A., Mensour, N., Sobczak, J., Hancock, I., and Russel, I.: Kappa-carrageenan gel immobilisation of lager brewing yeast. J. Inst. Brew., 105, 398404 (1999)

15. Šmogrovičová, D. and Dömény, Z.: Beer volatile by-product formation at different fermentation temperature using immobilised yeasts. Process Biochem., 34, 785-794 (1999).

16. Tata, M., Bower, P., Bromberg, S., Duncombe, D.,
Fehring, J., Lau, V. V., Ryder, D., and Stassi, P.: Immobilized yeast bioreactor systems for continuous beer fermentation. Biotechnol. Prog., 15, 105-113 (1999).

17. Brányik, T., Vicente, A. A., Machado Cruz, J. M., and Teixeira, J. A.: Spent grains - a new support for brewing yeast immobilisation. Biotechnol. Lett., 23, 1073-1078 (2001).

18. Brányik, T., Vicente, A. A., Machado Cruz, J. M., and Teixeira, J. A.: Continuous primary beer fermentation with brewing yeast immobilized on spent grains. J. Inst. Brew., 108, 410-415 (2002).

19. Honda, S., Nishimura, Y., Takahashi, M., Chiba, H., and Kakehi, K.: A manual method for the spectrophotometric determination of reducing carbohydrates with 2-cyanoacetamide. Anal. Biochem., 119, 194-199 (1982).

20. Miller, G. L.: Use of dinitrosalicylic acid reagent for determination of reducing sugars. Anal. Chem., 31, 426-428 (1954).

21. Bradford, M. M.: A rapid and sensitive method for the quantification of microgram quantities of protein utilizing the principle of protein-dye binding. Anal. Biochem., 72, 248254 (1976).

22. Henriques, M., Gasparetto, K., Azevedo, J., and Oliveira, R.: Experimental methodology to quantify Candida albicans cell surface hydrophobicity. Biotechnol. Lett., 24, 1111-1115 (2002).

23. van Oss, C. J., Chaudhury, M. K., and Good, R. J.: Interfacial Lifshitz-van der Walls and polar interaction in macroscopic systems. Chem. Rev., 88, 927-941 (1988).

24. van Oss, C. J.: Hydrophobicity of biosurfaces - origin, quantitative determination and interaction energies. Colloids Surf. B: Biointerfaces, 5, 91-110 (1995).

25. Gallardo-Moreno, A.M., Méndez-Vilas, A., GonzálezMartín, M. L., Nuevo, M. J., Bruque, J. M., Garduño, E., and Pérez-Giraldo, C.: Comparative study of the hydrophobicity of Candida parapsilosis 294 through macroscopic and microscopic analysis. Langmuir, 18, 3639-3644 (2002).

26. Pereira, M., Schwan, R., and Teixeira, J.: Isolation, screening, and characterisation of flocculating and pectinase producing Kluyveromyces strains. Food Technol. Biotechnol., 37, 257-261 (1999).

27. Sousa, M. L., Mota, M., and Teixeira, J. A.: Influence of operational parameters on the start up of a flocculation airlift bioreactor. Colloids Surf. B: Biointerfaces, 2, 181-188 (1994).

28. Winborne, M. P. and Rickard, P. A. D.: Pectinolytic activity of Saccharomyces fragilis cultured in controlled environments. Biotechnol. Bioeng., 20, 231-242 (1978).

29. Cruz-Guerrero, A., Bárzana, E., García-Garibay, M., and Gómez-Ruiz, L.: Dissolved oxygen threshold for the repression of endo-polygalacturonase production by Kluyveromyces marxianus. Process Biochem., 34, 621-624 (1999).

30. Pashova, S., Slokoska, L., Krumova, E., and Angelova, M.: Induction of polymethylgalacturonase biosynthesis cells of Aspergillus niger 26. Enzyme Microb. Technol., 24, 535540 (1999).

31. Cavalitto, S. F., Hours, R. A., and Mignone, C. F.: Growth and protopectinase production of Geotrichum klebahnii in batch and continuous cultures with synthetic media. J. Ind. Microbiol. Biotechnol., 25, 260-265 (2000).

32. Zheng, Z. and Shetty, K.: Solid state production of polygalacturonase by Lentinus edodes using fruit processing wastes. Process Biochem., 35, 825-830 (2000). 